\title{
As duas faces da moeda: arte e política no regime estético da contemporaneidade
}

\author{
The Two Faces of the Coin: Art and Politics \\ in the Aesthetic Regime of Contemporaneity
}

\section{Las dos faces de la moneda: arte y política en el régimen estético de la contemporaneidad}

\author{
Ricardo Maurício Gonzaga ${ }^{1}$
}

http://dx.doi.org/10.22409/poiesis.1830.147-169

\begin{abstract}
RESUMO: O texto aborda os problemas e riscos da aproximação da arte ao campo da política, a partir da perspectiva da crise da representação mimética e da vigência do "regime estético", conforme conceituado por Jacques Rancière, e aproximado à instauração do paradigma pós-histórico pelo advento das imagens técnicas, conforme proposto por Vilém Flusser. Nesta perspectiva, verifica-se que conceitos como "verdade", "ficção" e "engajamento" tornam-se passíveis de reavaliação.
\end{abstract}

PALAVRAS-CHAVE: arte; política; verdade; ficção; engajamento político; crise da representação

\footnotetext{
${ }^{1}$ Ricardo Maurício Gonzaga é artista visual e performático. Doutor em Artes Visuais pelo Programa de PósGraduação em Artes Visuais da EBA/UFRJ. Pós-doutorando pelo Programa de Pós-Graduação em Estudos Contemporâneos das Artes/PPGCA da Universidade Federal Fluminense. Professor associado do Departamento de Artes Visuais e do Programa de Pós-Graduação em Artes/PPGA da Universidade Federal do Espírito Santo. Líder do grupo de pesquisa CNPq/UFES Práticas e Processos da Performance. E-mail: ricmauz@gmail.com
} 
ABSTRACT: The text addresses the problems and risks of the approximation of art to the field of politics, from the perspective of the crisis of mimetic representation and the validity of the "aesthetic regime", as conceptualized by Jacques Rancière and approximated to the establishment of the post-historical paradigm by the advent of the technical images, as proposed by Vilém Flusser. In this perspective, it is verified how concepts such as "truth", "fiction" and "engagement" become amenable to reevaluation.

KEYWORDS: art; politics; truth; fiction; political engagement; crisis of representation

RESUMEN: El texto aborda los problemas y riesgos de la aproximación del arte al campo de la política, a partir de la perspectiva de la crisis de la representación mimética y de la vigencia del "régimen estético", según lo conceptuado por Jacques Rancière, y aproximado a la instauración del paradigma poshistórico por el en el advenimiento de las imágenes técnicas, según lo propuesto por Vilém Flusser. En esta perspectiva, se verifica cómo conceptos como "verdad", "ficción" y "compromiso" se vuelven a reevaluación.

PALABRAS CLAVE: arte; la política; la verdad; la ficción; compromiso político; crisis de la representación

Como citar: GONZAGA, Ricardo Maurício. As duas faces da moeda: arte e política no regime estético da contemporaneidade. Poiésis, Niterói, v. 18 , n. 30 , p. 147-169, dez. 2017.

doi: http://dx.doi.org/10.22409/poiesis.1830.147-169

Poiésis, Niterói, v. 18, n. 30, dez. 2017. 


\title{
As duas faces da moeda: arte e política no regime estético da contemporaneidade
}

\begin{abstract}
Arte e ativismo
No ano emblemático de 1968, Lygia Clark desabafava: "se eu fosse mais jovem, faria política. Eu me sinto pouco à vontade, muito integrada". (CLARK, 1980, p. 31) Manifestava assim o desconforto com sua percepção de uma nova situação do artista, já então, segundo ela, assimilado às estruturas sociais do status quo: "antes os artistas eram marginalizados, agora, nós, os propositores, estamos muito bem colocados no mundo. Chegamos a viver - propondo tudo. Há um lugar para nós na sociedade" (CLARK, 1980, p. 31), prosseguia, para em seguida vislumbrar uma alternativa social que parecia então ocupar o lugar, desafiador relativamente aos ímpetos de transformação política e social, de que os artistas, agora "integrados", pareciam a ela ter se distanciado:
\end{abstract}


Há outras espécies de pessoas que preparam o que vai acontecer, são outros precursores. A eles a sociedade continua a marginalizar. [...] esses jovens têm a mesma atitude existencial que nós, eles lançam processos de que não conhecem o fim, eles abrem caminham onde a saída é desconhecida. (CLARK, 1980, p. 31)

O incômodo de Clark parecia embutir uma percepção de certa impotência dos processos da arte quanto à possibilidade de transformação efetiva do real. À medida de sua "domesticação", o artista teria se tornado ser inócuo, cuja capacidade revolucionária tinha sido neutralizada, para dizer o mínimo.

Tal posição denota o que poderíamos denominar como certa nostalgia da "práxis vital", termo cunhado por Peter Bürger (2012), a partir de Habermas. Segundo ele, na sociedade burguesa, à medida que conquistava seu espaço de autonomia, a arte se distanciava da práxis vital da sociedade:

Arte sacra e arte cortesã estão, ainda que cada qual à sua maneira, incorporadas à práxis vital do receptor. Como objeto de culto, vale dizer, como objeto de representação, as obras de arte possuem uma finalidade de uso. Isso já não vale mais na mesma medida para a sociedade burguesa: a exibição da autocompreensão burguesa se dá num domínio da arte burguesa que se dá fora da práxis vital. (BÜRGER, 2012, p. 95)

Emblemática deste desejo de retorno à práxis vital, agora pela via do engajamento político, é a atitude de Ferreira Gullar que, naquele mesmo momento histórico - o da afirmação de Lygia Clark - decide pelo afastamento das preocupações experimentais do Neoconcretismo, fazendo a opção de se dedicar aos CPCs (Centros Populares de Cultura) da UNE (União Nacional dos Estudantes), em um processo de adesão radical às políticas de transformação social e política da sociedade.

Com a ampliação de seu campo, os capítulos seguintes da arte em sua história, específica e, simultaneamente, como derivação deste mesmo processo de expansão, contaminada pela realidade "externa" a ela e contaminando-a reciprocamente, traçariam o afastamento paulatino do "castelo da pureza" de seu espaço autônomo moderno. Neste percurso, os

Poiésis, Niterói, v. 18, n. 30, dez. 2017. 
riscos de que este afastamento gerasse certa perda progressiva do que poderia ser visto, se não como sua essência, ao menos como sua especificidade delimitadora de campo próprio, iriam se tornando mais e mais evidentes.

Mais de trinta anos depois, um trabalho da artista australiana Raquel Ormella revela preocupação similar à de Lygia Clark ao problematizar, um pouco ao modo de Joseph Kosuth em Uma e três cadeiras, os rumos contraditórios e os paradoxos percorridos pela questão da aproximação da arte à política, emergentes neste lapso de tempo: "Eu me preocupo que não seja suficientemente politizada" está escrito em uma das faces de um estandarte - de um conjunto de dois (Fig. 1) - similar aos que se vêem em manifestações de protesto mundo afora.

Ormella parece literalizar seu processo mental ao examinar instâncias desta aproximação entre arte e política: ambos os estandartes apresentam em seus versos descrições objetivas de situações, que apontam para o campo da política. Se reais ou ficcionais, não temos como verificar. No primeiro, que é o outro lado da frase mencionada acima com a reflexão autocrítica que a aproxima do inconformismo manifestado por Lygia Clark, lê-se: "O filho de Xanana Gusmão tem uma tatuagem do rosto do pai em seu peito"; no segundo, está escrito: "Um(a) amigo/a meu/minha passou uma noite com um cara que tinha ameaçado se imolar no foyer do Parlamento a menos que o governo Howard recebesse sua lista de demandas". Na face frontal deste, a frase "Eu me preocupo que isto se torne um slogan" parece dirigir-se autocriticamente, como conclusão, à lógica interna do trabalho e às dúvidas que resultam do processo de sua concepção e da reflexão que desencadeia, hipótese que parece se confirmar por ser o título do trabalho.

Ou seja, à objetividade das descrições, Ormella contrapõe a outra face da moeda, sintoma da inocência perdida: a reflexão que submete o processo à exigência de um recuo (auto)crítico, capaz de verificar, por meio do distanciamento, os rumos, sentidos e riscos inerentes à aproximação da arte ao engajamento político.

Neste ponto, quanto a esta aproximação, parece forçoso retornar mais uma vez à indagação recorrente: o que pode a arte? Em seguida, torna-se necessário especificar: o que 


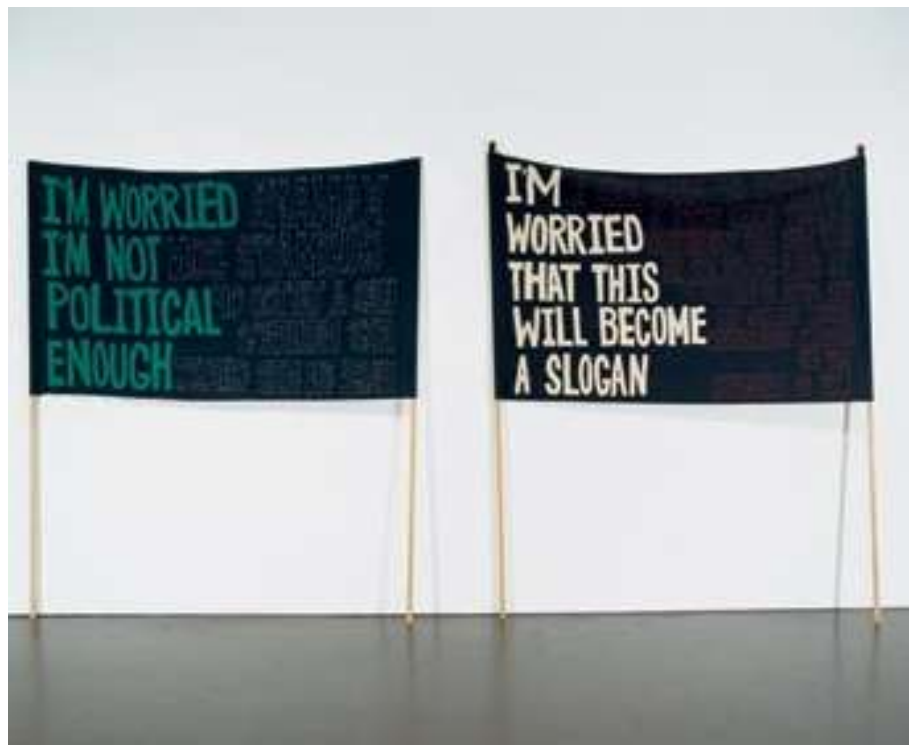

Fig. 1 - Raquel Ormella, Eu me preocupo que isto se torne um slogan, 1999-2002. estandartes de face dupla, lã e feltro costurados, $220 \times 200 \mathrm{~cm}$

(Fonte: http://johnmcdonald.net.au)

Poiésis, Niterói, v. 18, n. 30, dez. 2017. 
pode a arte no que se refere à transformação efetiva do real? Neste sentido cabe também indagar: é plausível atribuir à arte o poder de modificar as estruturas que organizam o real e, se o for, como ela opera para atingir este objetivo sem fugir de suas características ontológicas próprias, ou seja, sem deixar de ser arte, sem perda da perspectiva do horizonte de seu campo, ainda que expandido na contemporaneidade?

Jacques Rancière, em $O$ espectador emancipado, observa que "passado o tempo da denúncia do paradigma modernista e do ceticismo dominante quanto aos poderes subversivos da arte", nota-se agora uma reaproximação à crença na sua capacidade política "para responder às formas de dominação econômica, estatal e ideológica". (RANCIÈRE, 2012, p. 51) Em seguida a esta afirmação, Rancière lista vários exemplos de possibilidades que os trabalhos que pretendem enfrentar esta questão assumem, mas objeta que

essa diversidade não traduz apenas a variedade dos meios escolhidos para atingir o mesmo fim. Reflete uma incerteza mais fundamental sobre o fim em vista e sobre a própria configuração do terreno, sobre 0 que é a política e sobre o que a arte faz. (RANClèRE, 2012, p. 52)

Em seguida, menciona um fator que, no entanto, agrega todos estes trabalhos: a crença na eficácia do funcionamento de um regime ainda mimético, anterior à crise da representação. Segundo ele, tais trabalhos, em busca de seu objetivo comum - a luta política contra a dominação e a exploração - , confiam não só em sua capacidade de tornar visíveis as situações em que e pelas quais a injustiça se manifesta como também de, por meio delas e a partir desta percepção, mobilizar o público para a ação política contra as fontes do problema. Mas, como o próprio Rancière comenta, não há nada neste processo que possa garantir esta relação linear de causa e efeito entre estes três elementos: situação real, denúncia desta e mobilização para a ação - simplesmente porque este sistema se baseia em um modelo obsoleto, próprio "ao regime da mediação representativa e ao da imediatez ética" (RANCIÈRE, 2012, p. 58), como ele conceitua.

Rancière observa que, mais do que fundar-se na imitação do real, o regime representativo apoiava-se em uma ordem rígida, social, política e religiosa que determinava uma hie- 
rarquia de valores daquilo que a arte deveria mostrar - a superioridade da pintura histórica sobre a de gênero, ou a da tragédia sobre a comédia, por exemplo -, que espelhava representava - aquela ordem instituída.

A este regime, mimético, representacional, Rancière opõe a "eficácia estética" - uma "eficácia de suspensão", segundo ele - "do regime estético da arte". Ele especifica a natureza desta eficácia e de sua suspensão:

eficácia estética significa propriamente a suspensão de qualquer relação direta entre a produção das formas de arte e a produção de um efeito determinado sobre um público determinado. (RANClèRE, 2012, p. 58)

\section{Arte, realidade, verdade e ficção}

Em 2006, na 27a Bienal de São Paulo, o artista sueco Ola Pehrson apresentou uma instalação intitulada Caçada ao Unabomber, de 2005 (Fig. 2). Nela, o público assistia a um vídeo que supostamente apresentava de forma documental a trajetória do Unabomber,

o matemático, [...] pensador, escritor e ativista contra projetos que seguem direcionamentos expressos de fazer com que a inteligência artificial através das máquinas superem a soberania humana (matrix), preso sob a acusação de terrorismo e condenado à prisão perpétua por sua participação em uma série de atentados a bomba que mataram três pessoas e feriram outras 23. (WIKIPÉDIA)

No trabalho, à medida que as imagens do vídeo se sucedem, o espectador pode ter sua atenção desviada para uma estante fixada na parede ao lado, onde se alinham objetos produzidos artesanalmente de modo propositalmente tosco, para logo perceber que estes nada mais são que os referentes das imagens que assiste.

Para José Roca, o trabalho "sublinha o caráter ficcional daquilo que consideramos um 'documentário'". (ROCA apud LAGNADO; PEDROSA, 2006, p. 192) Ao entrevistar o artista, ele indaga:

Poiésis, Niterói, v. 18, n. 30, dez. 2017. 


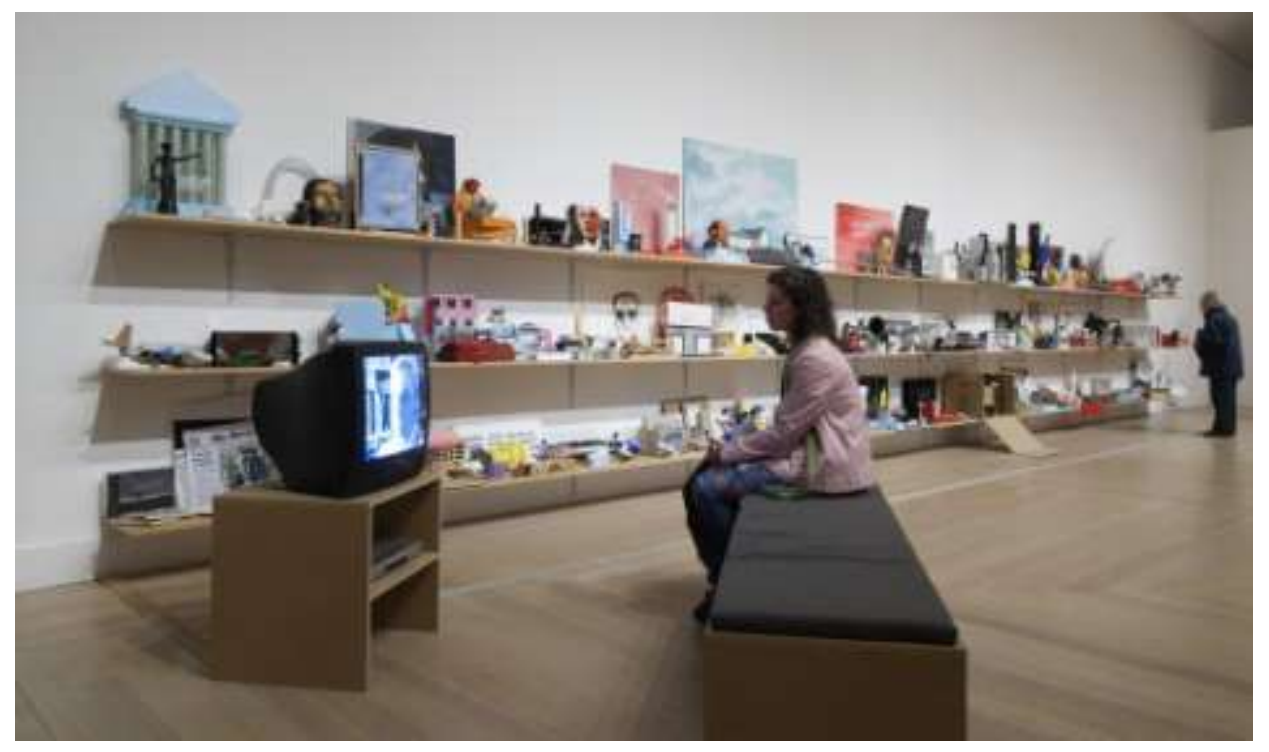

Fig. 2 - Ola Pehrson, Caçada ao Unabomber, 2005.

objetos em técnica mista e vídeo, dimensões variáveis

Coleção Moderna Museet, Estocolmo

(Fonte: https://hammer.ucla.edu/) 
[em Caçada ao Unabomber] você pretendia enfatizar o fato de que as imagens que conferem verdade a uma história são frequentemente fabricadas e que, na ausência de um material real, os produtores recorrem a imagens genéricas, encenações e depoimentos para construir uma história que, na realidade, é um simulacro da verdade? (ROCA apud LAGNADO; PEDROSA, 2006, p. 192)

Como resposta, Pehrson opta por descrever o processo de realização do trabalho:

Para esse trabalho recorri a um documentário real, mantive a trilha sonora e substituí todas as imagens pelas minhas de vídeo, filmando acessórios e construções simples, além de interpretar os diferentes papéis dos entrevistados. Tentei empregar o menor esforço para que as coisas parecessem reais, aproveitando as indicações visuais das imagens originais, refazendo-as com materiais simples e objetos reciclados. (PEHRSON apud LAGNADO; PEDROSA, 2006, p. 192)

O artista ressalta assim sua opção pela precariedade assumida em relação aos materiais na produção dos objetos que iriam gerar as imagens, o que parece ter como objetivo estimular o entendimento do espectador quanto à facilidade com que o processo de construção de "verdades documentais" pode se efetivar, consistindo a melhoria da qualidade das imagens apenas uma questão de grau e não de fundo. É como se o trabalho postulasse: "veja como a coisa toda funciona", abrindo, quase que didaticamente, para nossa apreciação crítica, o interior da caixa-preta da construção ideológica das verdades nossas de cada dia pela grande mídia.

Além disso, ao produzir esta inversão de sentido em relação à lógica da produção de imagens e apresentar, lado a lado, as imagens de vídeo e os objetos - evidentemente falsos e produzidos para gerá-las -, Pehrson apontava também os efeitos de nossa progressiva incapacidade de diferenciar o real dos "efeitos de realidade" gerados pela hegemonia paradigmática do universo das imagens técnicas como elementos mediadores de nossa percepção do real.

Poiésis, Niterói, v. 18, n. 30, dez. 2017. 
O que este paradigma define e como decorre deste processo um regime hegemônico gerador de certa descrença em relação à capacidade do signo - artístico ou não - funcionar como produtor de "verdades" em relação ao real?

Segundo Vilém Flusser, "imagens são mediações entre homem e mundo". Ele acrescenta: "o homem 'existe', isto é, o mundo não lhe é acessível imediatamente". (FLUSSER, 2002, p. 9) Disso decorre, ainda segundo Flusser, a necessidade humana de recorrer a - e criar - imagens e textos que tornem possível compreender e compartilhar a realidade com os demais membros do grupo social. Jacques Rancière, em A partilha do sensível, corrobora: "o real precisa ser ficcionado para ser pensado". (RANCIÈRE, 2009, p. 58) No entanto, como explicava Flusser, neste processo de produção de formas de mediação, acontecem movimentos retroativos, de feedback em relação ao real, em que estas, que foram criadas para tornar o real acessível ao entendimento, acabam por se confundir com ele.

Flusser divide a história ocidental em três períodos, pré-histórico, histórico e póshistórico, marcados pela alternância entre a hegemonia de imagens e textos e que têm como pontos de fundação e mutação a invenção de três formas de mediação: as primeiras pinturas parietais, os primeiros textos fonéticos e a invenção das imagens técnicas, sendo a primeira a fotografia. (FLUSSER, 1996) Segundo Flusser, os dois últimos surgem como meios de superação dos impasses provocados por momentos de idolatria e textolatria respectivamente, que tornavam opacos os instrumentos de mediação com o real, a saber, imagens e textos, que deveriam explicá-lo.

Assim, para Flusser, a fase histórica do Ocidente teria encontrado seu limite quando "conceituação virou textolatria" e os textos hegemônicos que deveriam produzir explicações escritas do real - "ler" o mundo em sua verdade prévia - atingiram um ponto de exaustão e encontraram o limite de sua eficácia quando a compreensão coletiva passou a se abrir monoliticamente, direcionada por leituras exclusivas e excludentes, flagrantemente contraditórias ao espírito de liberdade originário que as produzira. (FLUSSER, 1996, p. 66) Então, com o advento da fotografia, um novo momento - pós-histórico - de hegemo- 
nia da imagem - agora técnica, isto é, segundo Flusser, produzida por aparelhos, viria a inaugurar uma nova forma de mediação com o real.

Neste ponto podemos aproximar o pensamento de Flusser ao de Rancière: se as imagens do "regime mimético de representação" - mencionado pelo segundo - que se limitavam a ilustrar os textos do "período histórico" definido pelo primeiro, baseavam-se em certa ordem - política, social, econômica e religiosa - instituída, com a ruptura desta, perdem toda sua capacidade de significar.

Neste caso, a crise do texto como paradigma cultural seria apenas um aspecto de outra maior: a crise do sistema clássico de representação. Em sua vigência, representar significava apresentar de novo algo em cuja existência se acredita sem dúvida, logo, a crise da representação, crise do Verbo como Verdade absoluta, de origem divina, teria se configurado, portanto, como um aspecto de um movimento geral de transformações políticas, filosóficas e sociais, emergindo em coerência com noções e fatos tais como a morte de Deus, a decapitação do rei e a proclamação da república (res publica).

No âmbito da arte, a falência deste dispositivo iria se valer da irrupção do novo "evento crucial" que estabeleceria o fim do período histórico ocidental, de acordo com Flusser: a invenção da fotografia, a primeira das imagens técnicas. Segundo ele, as imagens técnicas não representam o mundo, elas vão constituir o mundo a partir de sua capacidade de tornar conceitos visíveis. (FLUSSER, 1996)

Uma mudança radical, uma inversão vetorial na dinâmica de produção da significação: na primeira situação, o significado vem do mundo, é preciso extraí-lo dele, portanto, representar o mundo. Na segunda, percebe-se que o significado do mundo não está lá, à espera de ser revelado - representado, mas se dá a partir de nosso contato com ele: não há significado no mundo a não ser o que nele projetamos. Agora, torna-se preciso, portanto, por assim dizer, "pro-presentar" (GONZAGA, 2006) o mundo e o pensamento conceitual adquire nova função: "serve, não mais para explicar o mundo, mas para dar-lhe

Poiésis, Niterói, v. 18, n. 30, dez. 2017. 
sentido", colaborar "com a nova imaginação na sua tarefa de dar significado ao mundo". (FLUSSER, 1996, p. 68) Torna-se, segundo Flusser, "pré-texto". (FLUSSER, 1985)

Flusser acrescenta que esta mudança de perspectiva gera uma importante alteração na forma como se organizam os campos do saber: com suas estratégias de objetividade, que intentavam revelar a verdade do mundo, a ciência

deixará de ser disciplina que explica e passará a ser disciplina que confere significado [...], o que a transformará em disciplina artística, já que a arte (o pensamento imaginativo) sempre procurava conferir significado. Ora, ciência como uma arte entre outras obrigará repensarmos conceitos como "verdade" $\mathrm{e}$ "conhecimento". (FLUSSER, 1996, p. 68)

Ciência como arte; uma reviravolta sem precedentes na história do Ocidente. No entanto, como observa Jacques Rancière,

não se trata de dizer que tudo é ficção. Trata-se de constatar que a ficção da era estética definiu modelos de conexão entre apresentação dos fatos e formas de inteligibilidade que tornam indefinida a fronteira entre razão dos fatos e razão da ficção, e que esses modos de conexão foram retomados pelos historiadores e analistas da realidade social. (RANAĖRE, 2009, p. 58)

A este respeito, parece oportuno citar Jean Baudrillard: "no tempo histórico, o acontecimento ocorreu e as provas estão aí, [...] no tempo real não há mais provas de nada". (BAUDRILLARD, 2002, p. 58) Baudrillard usa como exemplo o fenômeno do negacionismo, ou seja, a negação do holocausto judeu:

a questão crucial passa a ser: [...] por que a existência das câmaras de gás pode ser questionada? Em outros tempos teria sido impossível [...]. Ora o próprio fato de ter de defender a realidade histórica das câmaras de gás como causa moral, de ter de defender a 'realidade' em geral através de uma espécie de engajamento político, testemunha fortemente sobre a mudança de registro da verdade histórica e sobre as turbulências da objetividade. (BAUDRILLARD, 2002, p. 58) 
O que confere ao problema toda sua gravidade é que, como observa Baudrillard, tal posição absurda é favorecida pelo fato de que "a exterminação nunca será verificada em tempo real". Baudrillard aponta: "os campos de exterminação tornam-se aí virtuais [...], caem no mesmo abismo virtual - o de acontecimentos ou de fatos que existem o tempo que existem, ponto, nada mais". (BAUDRILLARD, 2002, p. 58-59) Ou seja: em última instância, a história corre o risco de se tornar uma questão de crença, sujeita aos fluxos da propaganda contínua e da disputa política, em tempo real.

Vale agora retornar a Rancière: "os enunciados políticos ou literários fazem efeito no real. [...] Traçam mapas do visível, trajetórias entre o visível e o dizível, relações entre modos do ser, modos do fazer e modos do dizer". (RANCIÈRE, 2009, p. 59) Deriva daí a necessidade de reapresentação continuada das evidências - de genocídios, em museus, por exemplo - como forma de resgate permanente da memória na "tela total" (Baudrillard, 2002) da contemporaneidade.

Portanto, como vimos até aqui, superado o momento da autonomia da arte que se concentrara na lógica interna, sintática do trabalho, e que, quanto à capacidade de transbordamento político apoiava-se na expectativa - dos neoplasticistas, por exemplo - de que o quadro servisse como modelo ético/estético para a transformação do mundo; momento, portanto, de predomínio de um regime de presentação da arte, que se contrapunha ao da representação pré-moderna, o artista agora é livre, em regime de "propresentação", para projetar significados, ficções que procuram produzir transformações nos "regimes de visibilidade" do real, mencionados por Rancière. Segundo ele: "a política e a arte, tanto quanto os saberes, constroem "ficções", isto é, rearranjos materiais dos signos e das imagens, das relações entre o que se vê e o que se diz, entre o que se faz e o que se pode fazer". (RANCIÈRE, 2009, p. 59)

Na contemporaneidade, a arte se vale destes procedimentos de construção ficcional para produzir e defender versões alternativas, alegóricas (alegoria, do grego alle egorei, diz: "outra fala") sobre a realidade, capazes de despertar reflexões críticas - portanto, políticas - na recepção. Por esta via, instaura-se uma abertura prospectiva que implica em

Poiésis, Niterói, v. 18, n. 30, dez. 2017. 
uma desvalorização do espaço semântico em prol dos efeitos pragmáticos, propresentativos, do processo. Estes efeitos, produtores de oscilações alegóricas, implicam, portanto, consequentemente, em um aumento da importância do receptor, a quem caberá (r)estabelecer - ou não - sentido ao processo.

Esta abertura fundamental, mais do que uma simples possibilidade, afirma-se como exigência para o trabalho de arte funcionar no regime estético como o regime de suspensão conceituado por Rancière, isto é, à distância da noção de pré-textos ideológicos, sob pena de retorno ao modo de crença, fundamentado em verdades absolutas, próprio ao regime mimético de representação. Em caso contrário, o slogan ideológico volta a ocupar o lugar do texto hegemônico característico do momento da crise textólatra, assumindo pretensamente certo caráter de nova "verdade religiosa" e o trabalho de arte volta a paralisar sua potência crítica e significante, reduzindo-se mais uma vez ao papel de mero ilustrador de "verdades" apriorísticas.

\section{Literalização em objetos e procedimentos híbridos da arte política}

Em 2003, Raul Mourão realiza o Luladepelúcia, boneco de pelúcia que transferia a imagem do então presidente do Brasil, Luiz Inácio Lula da Silva, para um boneco de pelúcia (Fig. 3).

A ambiguidade polissêmica do objeto fazia com que pudesse, segundo Daniela Labra (2005), "ser entendido como ataque veemente ou homenagem cândida ao Presidente da República", possibilidades ampliadas posteriormente pelas circunstâncias que acirraram o debate político no país e polarizaram o debate a ponto de sua asfixia. Como "um boneco de Dorian Gray", na feliz expressão de Marcelo Pereira (2005), o Luladepelucia sofre mutações em sua percepção na recepção, à medida que a cena política evolui. Como lembrava Pereira, no momento em que escrevia, em 2005: 


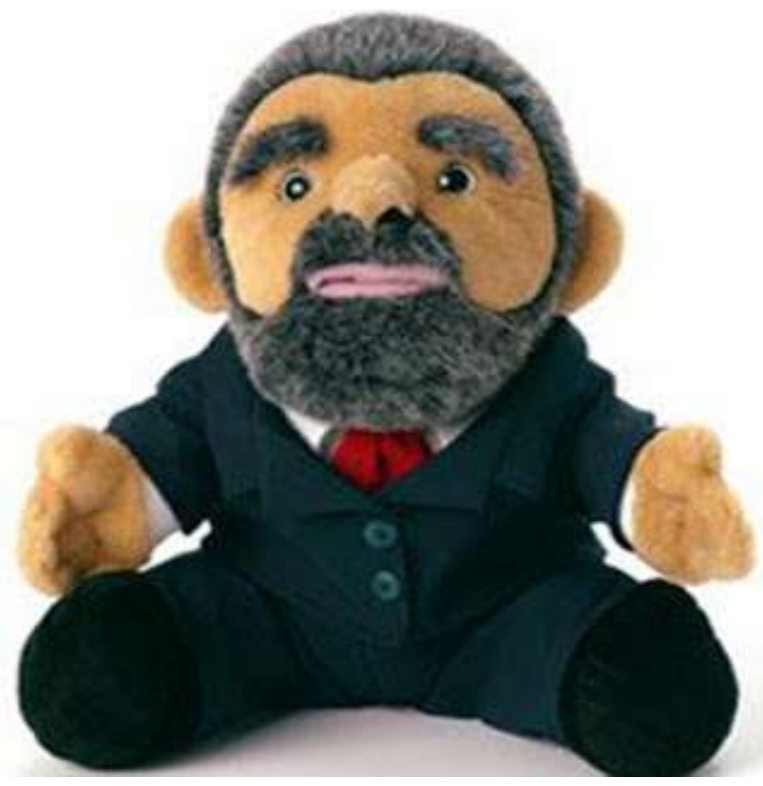

Fig. 3 - Raul Mourão, Luladepelúcia, 2003.

objeto de pelúcia

(Fonte: http://www.overmundo.com.br/)

Poiésis, Niterói, v. 18, n. 30, dez. 2017. 
O presidente, seu governo e seu partido estão envolvidos numa sucessão de escândalos que aponta para o maior esquema de corrupção que já vimos. [...] 0 rei está nu e o sonho acabou.

Luladepelúcia também sofreu mutações. [...] Se repararmos bem, não é mais assim tão fofo. Pensamos duas vezes antes de querer abraçá-lo. Ali há algo de brinquedo-assassino em sua expressão não muito amigável. (PEREIRA, 2005)

O Luladepelúcia não é um retrato do político, mas um "póstrato": seu sentido está, não à deriva, mas livre para possíveis reinterpretações, múltiplas e variadas, que põem em andamento a discussão e o dissenso político. Como lembra Labra: "se, antes dos escândalos, Luladepelúcia não passava de brincadeira, talvez ironia" (LABRA, 2005) - ou, nas palavras de Pereira: "um presidente-bibelô, um ursinho barbudo, uma coisa fofa para apertar, abraçar e dormir junto nos momentos de angústia" (PEREIRA, 2005) -, "na conjuntura de hoje e de acordo com as notícias de amanhã, pode ser entendido como ataque veemente ou homenagem cândida ao Presidente da República". (LABRA, 2005) Ou seja, como conclui Labra: "o sentido mais profundo de sua mensagem permanece aberto" - e é justamente desta abertura que o trabalho tira seu potencial de instauração, político e polêmico.

A potência política desta abertura de sentido aparece também no trabalho recente de dois artistas colombianos: Nadín Ospina, que criou, em cerâmica e pedra, objetos híbridos que fundem em um gesto irônico o patrimônio físico da herança cultural pré-colombiana a imagens do universo dos personagens de Walt Disney ou do desenho animado Os Simpsons. Estas esculturas inserem com mordacidade no ambiente de exposição a face amarga, mas simultaneamente bem-humorada, da relação das culturas latino-americanas com a invasão das imagens do imperialismo cultural dos Estados Unidos da América. No entanto, o trabalho deriva em parte seu fascínio da dimensão intrigante proveniente da fusão de tempos e culturas que emana destes objetos, a um tempo ambiguamente críticos, divertidos e solenes (Fig. 4). 


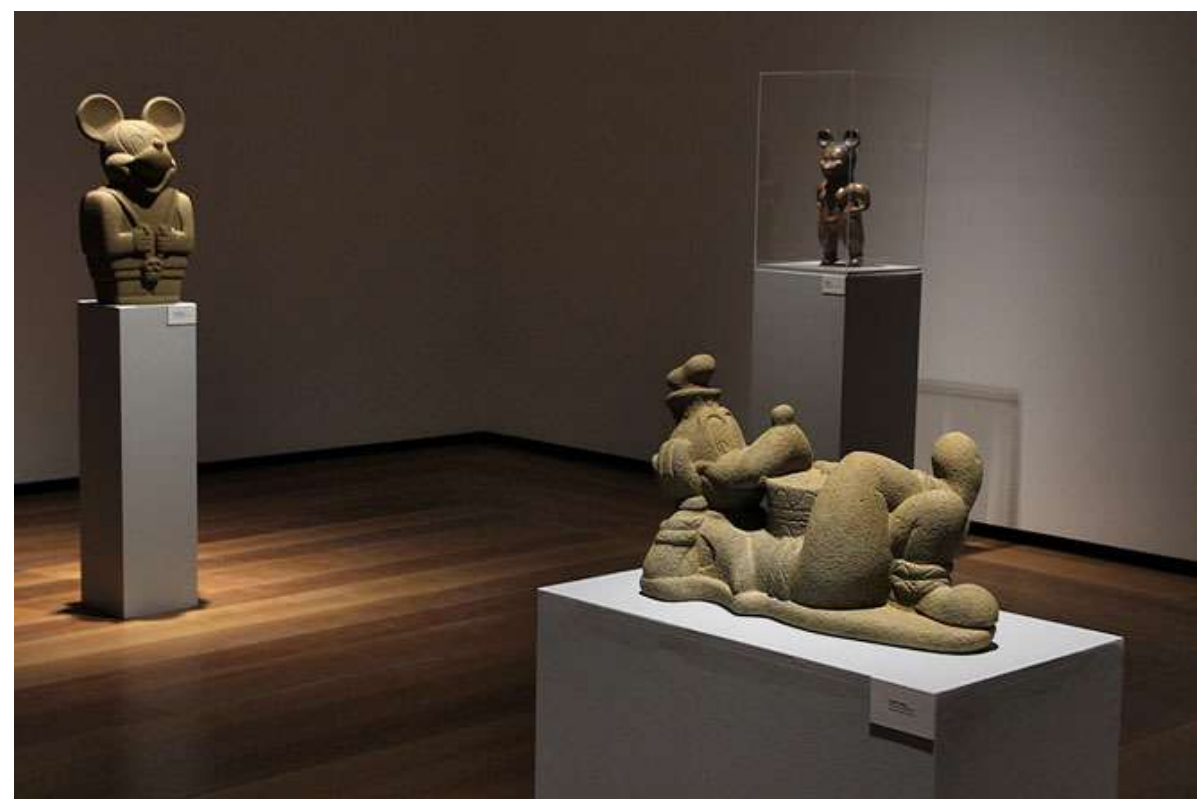

Fig. 4 - Vista da sala de Nadín Ospina, na exposição Cantos Cuentos Colombianos: arte contemporáneo colombiano, Casa Daros, Rio de Janeiro, Brasil, 2013.

(Fonte: https://noticias.bol.uol.com.br/fotos/entretenimento/)

Poiésis, Niterói, v. 18, n. 30, dez. 2017. 
A ambiguidade destas fusões híbridas se manifesta de forma mais contundente em Caixão Lego, de Fernando Arias (Fig. 5). Aqui, pecinhas de montar do jogo Lego, mundialmente reconhecidas como resultado da globalização, constroem um caixão com as cores da bandeira da Colômbia. Se a "mensagem" aqui é mais direta e inescapável, o espaço de possível ressignificação se mantém, agora congelado no silêncio solene da visão híbrida deste objeto, na atração simultaneamente cruel e fascinante de sua limpeza formal. Parafraseando Didi-Huberman, podemos indagar: "o que vemos e como nos olha" este objeto, a um tempo mórbido e lúdico, do fundo de seu silêncio admoestativo?

Dúvida semelhante emerge do trabalho Las reglas del juego/The rules of the game, que o artista mexicano Gustavo Artigas realizou no ginásio de esportes de um colégio de ensino secundário de Tijuana, no México (Fig. 6). Como descreve Luiz Sérgio de Oliveira, "o projeto tratou da realização de dois jogos simultâneos. Dois jogos cada qual com suas regras [...] futebol de salão [...] basquetebol. Dois jogos/um jogo. Disputados no mesmo espaço, no mesmo dia, na mesma hora". (OLIVEIRA, 2013, p. 10)

Em uma cidade de fronteira, território de convivência por vezes violenta entre duas culturas, a arte faz superpor os jogos prediletos dos jovens das respectivas comunidades: futebol para os mexicanos, basquete para os nativos dos Estados Unidos, fazendo emergir, talvez, na visão de Jennie Klein citada por Oliveira, uma "metáfora para a necessidade de se encontrar meios de coexistência pacífica diante das diferenças". (KLEIN apud OLIVEIRA, 2013, p. 10) Já Leah Ollman surpreendeu-se com a pouca interação ocorrida entre os atletas dos dois jogos, que permaneceram "focados em suas próprias [...] oportunidades de pontuar ou marcar". (OLLMAN apud OLIVEIRA, 2013, p.10-11) Porém, como observa Oliveira, "é possível que a fricção que faltou dentro da quadra tenha grassado pelos diferentes níveis das arquibancadas ocupados por habitantes de dois mundos: o da arte e do mundo mundano". (OLIVEIRA, 2013, p. 11)

Friç̧ão que, à distância de sua primeira eclosão, se projeta e se amplia no tempo e cuja ambiguidade parece ter sido capturada e figurada pela fotografia do momento em que as duas bolas dos respectivos jogos atingem a cesta do jogo de basquete, a sintetizar magicamente a potência política do trabalho como instrumento de reflexão crítica frente à situação real. 


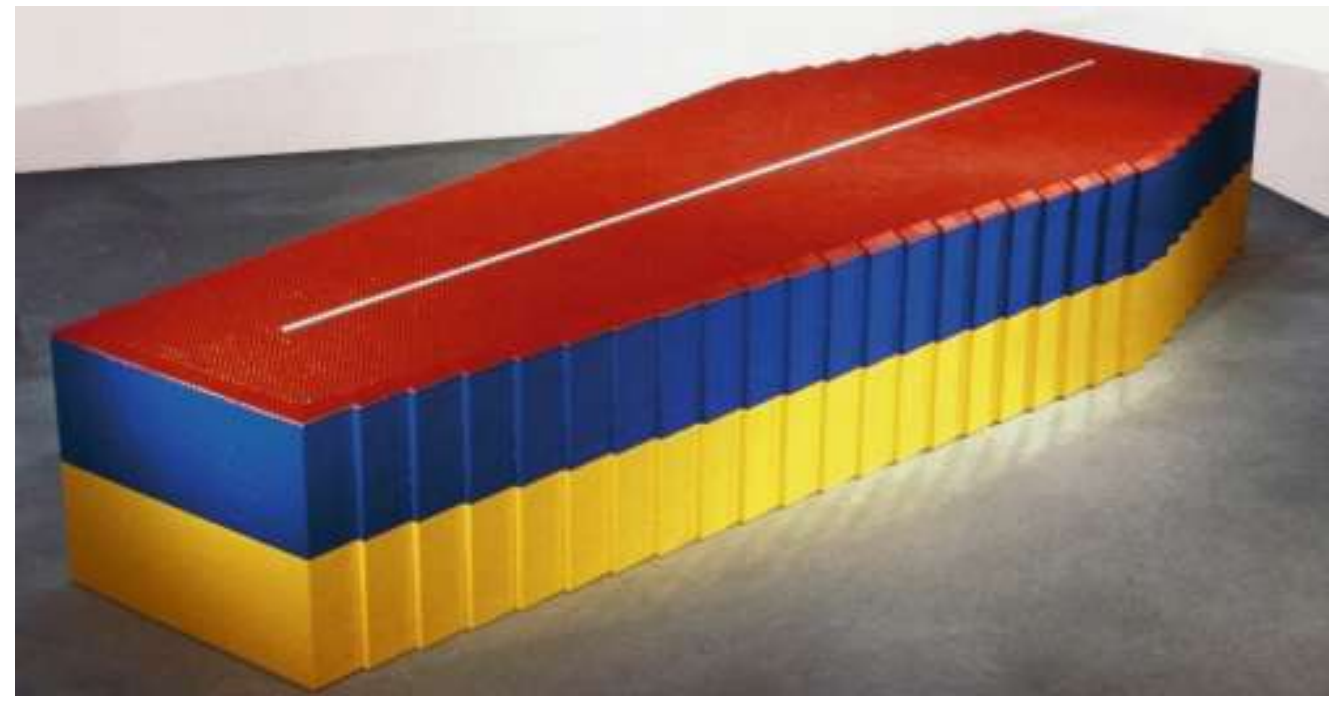

Fig. 5 - Fernando Arias, Caixão Lego (Homenagem às crianças da guerra das drogas), 2000. Lego e madeira compensada, $28.5 \times 190.5 \times 70 \mathrm{~cm}$.

Coleção Daros Latinamérica, Zurique, Suíça

(Fonte: https://noticias.bol.uol.com.br/fotos/entretenimento/)

Poiésis, Niterói, v. 18, n. 30, dez. 2017. 


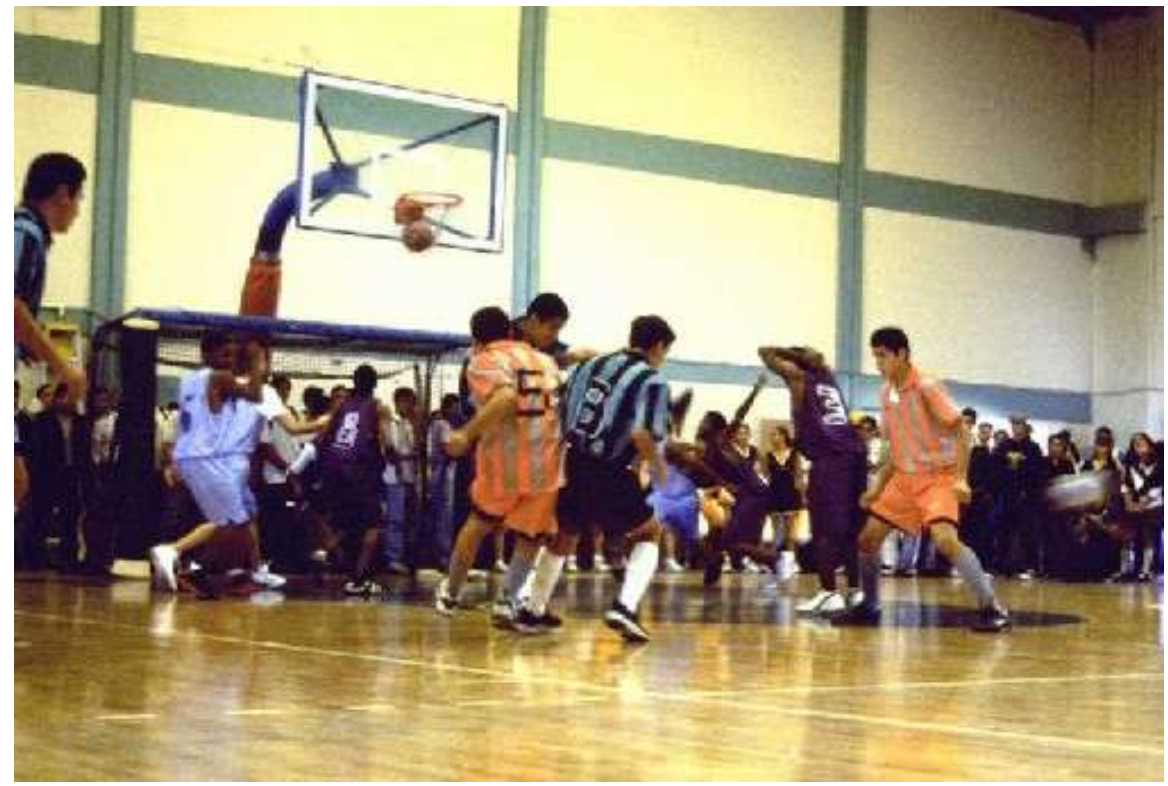

Fig. 6 - Gustavo Artigas, Las reglas del juego/The Rules of the Game, 2000-2001. projeto desenvolvido para o inSITE (San Diego-Tijuana)

(Fonte: http://www.newappsblog.com/2010/) 
Duas bolas, dois jogos, duas regras: da arte e da política. Exigência para aquela no exercício de aproximação direta a esta: manter a abertura das ressignificações polissêmicas capazes de abrir também o exercício do dissenso político.

Sob pena de, a distância desta, o pré-texto artístico se engessar em slogan.

Sob pena, então, de a arte fazer má política.

E pior arte.

\section{Referências}

BAUDRILLARD, Jean. Tela total, Porto Alegre: Sulina, 2002.

BÜRGER, Peter. Teoria da vanguarda, São Paulo: Cosac Naify, 2012.

CLARK, Lygia. Lygia Clark, Rio de Janeiro: FUNARTE, 1980.

FLUSSER, Vilém. Filosofia da Caixa Preta. Rio de Janeiro: Relume Dumará, 2002.

FLUSSER, Vilém. Prétextos para a poesia. Cadernos RioArte, ano I, n. 3, 1985.

FLUSSER, Vilém . Texto/ Imagem enquanto Dinâmica do Ocidente. Caderno RioArte, ano II, n. 5, 1996.

GONZAGA, Ricardo Maurício. Read Me, Ready Me: a caixa-preta do ser em tempo real. Arte \& Ensaios, Revista do Programa de Pós-Graduação em Artes Visuais (EBA-UFRJ), Rio de Janeiro, v. 13, n. 13, 2006.

LABRA, Daniela. Luladepelúcia, 2005. Disponível em http://www.raulmourao.com/luladepelucia-texto/. Acesso em 2/6/2017.

LANGNADO, Lisette; PEDROSA, Adriano (eds.). Como viver junto: Guia da 27a Bienal de São Paulo. São Paulo: Fundação Bienal, 2016.

Poiésis, Niterói, v. 18, n. 30, dez. 2017. 
OLIVEIRA, Luiz Sérgio de. Invisibilidade entre muitos: o corpo e a natureza política da arte contemporânea. In: UFPA. Anais do VI Fórum Bienal de Pesquisa em Artes, 2013, Belém, Pará. Corpos entre Artes | Artes entre Corpos: VI Fórum Bienal de Pesquisa em Artes da UFPA. Belém, Pará: UFPA, 2013. v. 1.

PEREIRA, Marcelo, Um boneco de Dorian Gray, 2005. Disponível em http://www.raul mourao.com/um-boneco-de-dorian-gray-2005/. Acesso em 2/6/2017.

RANCIÈRE, Jacques. A partilha do sensível: estética e política, São Paulo: EXO; Editora 34, 2009.

RANCIÈRE, Jacques. O espectador emancipado. São Paulo: Martins Fontes, 2012. 